\title{
INEQUALITY AND REDISTRIBUTION VIA THE Public Provision of Private Goods
}

\author{
MARGARITA KATSIMI AND THOMAS MOUTOS
}

CESIFO WORKING PAPER No. 1121

CATEgORY 1: PUBlic FinANCE

JANUARY 2004

An electronic version of the paper may be downloaded

- from the SSRN website: www.SSRN.com

- from the CESifo website: www.CESifo.de 


\title{
INEQUALITY AN REDISTRIBUTION VIA THE Public Provision of PRIVATE GoOdS
}

\begin{abstract}
The relationship between inequality and redistribution is usually studied under the assumption that the government collects different amounts of taxes from each citizen (voter) but gives back the same amount (in cash or in kind) to everyone. In this paper we consider what happens if the government can redistribute through both sides of its budget (revenue and expenditure). We show that inequality may have no discernible effect on the size of redistributive programs.
\end{abstract}

JEL Classification: H23, H42, P16.

Keywords: redistribution, inequality, public goods, median voter.

Margarita Katsimi

Athens University of Economics and

Business

Patission 76

Athens 10434

Greece

mkatsimi@aueb.gr
Thomas Moutos

Athens University of Economics and

Business

Patission 76

Athens 10434

Greece

tmoutos@aueb.gr

Without implicating, we wish to thank Lambros Pechlivanos, Euclid Tsakalotos and Spyros Vassilakis for useful comments and suggestions. 


\section{Introduction}

Following the influential contributions of Meltzer and Richard (1981), Alesina and Rodrik (1994) and Persson and Tabellini (1994), the conventional wisdom is that higher income inequality among voters leads to increased government redistribution. The intuition behind this result is that the greater is the gap between median and mean income, the higher will be the level of spending preferred by the median income voter and - since political competition drives policy decisions toward the ideal point of the median income voter - the higher will be the equilibrium amount of redistribution. Nevertheless, despite some empirical evidence in support of this hypothesis (see, Meltzer and Richard (1983), Milanovic (2000)), other empirical studies have not found that higher income inequality among voters leads to an increase in the size of redistributive programs (see, for example, Perotti (1996) and Rodriguez (1999)). This has led some (e.g., Benabou (1996) and Rodriguez (1999)) to urge the profession to take seriously the need to relax median voter assumptions in order to gain an understanding in variations in redistributive activity across countries and over time.

Political scientists have long argued that unadulterated, fully participatory, median-voter democracy describes no actual political system - rather, the translation of resources into influence occurs in highly institutionalized environments that amplify some voices and mute others. Although we do not want to dispute the validity of this claim, in this paper we show that, in a median-voter framework, the relationship between inequality and redistribution is not always positive once we take into account that redistribution is often effected through the public provision of private goods ${ }^{1}$. For this purpose we construct a model in which the government uses the tax proceeds to finance the provision of a rival public good which is

\footnotetext{
${ }^{1}$ Other papers showing that there is not, necessarily, a divergence between theory (based on the median-voter framework) and empirical evidence include Lee and Roemer (1999), Benabou (2000) and Alesina, Glaeser and Sacerdote (2001).
} 
also provided by the private sector, albeit at different quality levels - a vertically differentiated product (VDP) like health or education. Households are assumed to derive utility from the consumption of the VDP (either of the variety freely provided by the government or of one of the varieties offered by the private sector) and of a privately produced homogeneous product. We assume that both goods are rival in consumption. This implies that if a higher proportion of households decide to "consume" the publicly provided variety, the quality provided by the public sector must decline. Thus, although for a given level of public consumption the median voter would have chosen to vote for a higher tax rate in response to higher income inequality, a rise in the tax rate may induce a larger number of the more wealthy households to consume the publicly provided variety (since their after-tax income declines). Consequently, the rise in the tax rate may leave the median voter with lower after-tax income without a corresponding rise in the quality of the publicly-provided variety. As a result, the median voter may not prefer a rise in the tax rate as inequality increases.

\section{The Model}

We construct the simplest possible model capable of illustrating the main idea of the paper. To this end, consider a closed economy which produces and consumes two goods ( $\mathrm{X}$ and $\mathrm{Y}$ ) with the use of labour. We assume that perfect competition prevails in all markets and that all households (citizens-cum-voters) are endowed with one unit of labor, which they offer inelastically. There are, however, differences in skill between households, which are reflected in differences in the endowment of each household's effective labor supply. This is in turn reflected in differences in income across households. We assume that firms pay the same wage rate per effective unit of labor -thus the distribution of talent across firms does 
not affect unit production costs. We will assume that the politico-economic equilibrium is determined according to the Downsian model of electoral competition.

\section{a. Firms}

Good $\mathrm{X}$ is a homogeneous good produced only by private sector firms under linear technology,

$$
X=L
$$

where $L$ stands for the effective units of labour used. Using labour as the numeraire, we get that the price of $\operatorname{good} X, p_{X}$, is unity.

Good $Y$ is a vertically differentiated good (VDP) which is produced at various quality levels in both the private and the public sector. We wish to capture the fact that, for many government-provided goods (or services), some citizens choose not to "consume" them (even though they are eligible for doing so and there is no price-tag attached to them), preferring instead to purchase them from the private sector. Typical examples of such publicly provided goods are health care, childcare, old-age care and education. One reason for this phenomenon is that these goods are vertically differentiated according to quality (thus displaying large income elasticity) and there is a large degree of lumpiness associated with their consumption. For example, it is nearly impossible for a student to attend at the same time a public and a private educational institution (or to attend both part-time thus achieving a full-time status), or for a patient to have part of a heart operation at a public hospital and the rest of the operation at a private one. Moreover, in many cases it confers no extra utility (or it is detrimental) to supplement publicly provided goods with privately provided ones (i.e., first having an operation at a public hospital and afterwards supplementing it with another operation at a private hospital). Wealthy households will often elect to pay in order to avail 
themselves of the highest quality of these services - rather than be satisfied with the (sometimes) mediocre quality offered by the public sector.

We assume that quality is measured by an index $Q>0$, and that there is complete information regarding the quality index. We further assume that average costs depend on quality and that, for any given quality level, the average cost is independent of the number of units produced. These assumptions are captured by the following production function, $Y_{Q}=L / Q$

In equation (2), $Y_{Q}$ denotes the number of units of quality $Q$ produced. This particular specification implies that as quality increases more (effective) units of labour are required to produce each unit of the $Y$ good. It also implies that the (average cost) and price at which each variety of the good will be offered is

$P(Q)=Q$

For simplicity, and without loss of generality, we assume that the public sector uses the same technology to produce the good, and pays the same wage rate.

\section{b. Households}

All households are assumed to have identical preferences. Following Flam and Helpman (1987), we assume that the homogeneous good is divisible, whereas the qualitydifferentiated product is indivisible and households can consume only one unit of it. For simplicity - and with some loss of generality - we write the utility function as

$$
U_{i}=Q_{i}+\ln X_{i}
$$

where $X_{i}$ and $Q_{i}$ stand for the quantity of the homogeneous good and the quality of good $Y$ (the VDP) consumed by household $i$. In addition to simplicity, this quasi-linear utility function has the advantage that it generates a prediction that the size of the public sector 
evolves according to Wagner's Law (i.e. the share of government spending in GNP is positively related to per-capita GNP). Moreover, we have verified that the results obtained in this paper can be generated by other utility functions (for example, $U=\gamma Q+[X /(1-\pi)]^{1-\pi}$ ). Let $e_{i}$ stand for household's $i$ endowment of effective number of labour units. Since the wage rate per effective units of labour is unity, $e_{i}$ also stands for household income. We assume that there is a continuum of households, $i \in[0,1]$, with Pareto distributed incomes. The Pareto distribution is defined over the interval $e \geq b$, and its CDF is

$$
F(e)=1-(b / e)^{a}, a>1 .
$$

Parameter $b$ stands for the lowest income, and parameter $a$ determines the shape of the distribution (higher values of $a$ imply greater equality). The Pareto distribution, in addition to being easy to work with, is a good approximation of actual income distributions. Empirical estimates of the value of $a$ range between 1.5 and 3.0 (see, Creedy (1977)). The mean of the Pareto distribution is equal to

$$
\mu=a b /(a-1)
$$

and the income of the median voter (household) is

$$
m=2^{1 / a} b
$$

Since good $\mathrm{Y}$ is also offered by the public sector, and households can consume either a privately-provided variety or the (single) variety provided by the government, in effect households face two mutually exclusive budget constraints. The budget constraint of a household deciding to acquire a variety of $\mathrm{Y}$ which is offered by the private sector is

$$
e_{i}(1-t)=P(Q)+P_{X} X_{i}=Q_{i}+X_{i} \text {, }
$$

whereas, if the household chooses to consume the publicly (and freely) provided variety the budget constraint is,

$$
e_{i}(1-t)=X_{i}
$$


where $t$ stands for the income tax rate. Let $Q^{G}$ stand for the quality of good $Y$ provided by the public sector. Then, if the household consumes a privately provided variety, the utility maximizing demands for $Q$ and $X$ are (we assume that for all households income is high enough to generate positive demand for both goods),

$Q_{i}=e_{i}(1-t)-1$

$X_{i}=1$,

whereas if the household consumes the publicly provided variety, the entire disposable income of the household $\left(=e_{i}(1-t)\right)$ is spent on $X$.

The resulting indirect utility of the household in the two cases is then,

$V_{i}^{P}=e_{i}(1-t)-1, \quad$ if it chooses a privately-offered variety,

$V_{i}^{G}=Q^{G}+\ln \left(e_{i}(1-t)\right)$, if it consumes the publicly-offered variety.

We note that the difference between $V_{i}^{P}$ and $V_{i}^{G}$ is increasing in income (e). Thus, only households with large incomes will be willing to pass by the possibility of consuming for free the publicly provided variety and instead pay to acquire their preferred variety from the private sector. Let $\theta$ denote the income of a household that is indifferent between consuming the publicly provided variety and its optimally chosen privately produced variety, i.e., for this household it holds that

$V^{P}=\theta(1-t)-1=Q^{G}+\ln (\theta(1-t))=V^{G}$.

We term $\theta$ the dividing level of income (ability). From the Pareto distribution we know that the proportion of households with incomes smaller or equal to $\theta$ (that is, the proportion of households which choose to consume the publicly provided variety) is $F(\theta)=1-(b / \theta)^{a}$.

Assuming that the government budget is kept in balance, we have that 
$t \mu=\left[1-(b / \theta)^{a}\right] Q^{G}$.

In equation (11) the left-hand-side stands for tax revenue and the right-hand-side for the cost of providing the $Y$ good at quality $Q^{G}$ to all those wishing to consume it. Thus, the relationship between the tax rate and $Q^{G}$ depends on how many households consume the publicly provided variety. Rewriting equation (11) we get that

$Q^{G}=t b a /(a-1)\left(1-(b / \theta)^{a}\right)$.

\section{Median-voter equilibrium}

In what follows we concentrate on the median voter (it can be easily established that all the conditions required for the median-voter theorem to apply are satisfied). In the politicoeconomic equilibrium considered in this paper, the prevailing tax rate implemented by the policy maker is the one that maximizes the utility of the median voter.

Substituting equation (12) into equations (8) and (9) and using equation (5b), we get that

$V_{m}^{P}=b 2^{1 / a}(1-t)-1$

$V_{m}^{G}=\frac{t b a}{(a-1)\left(1-(b / \theta)^{a}\right)}+\ln \left(b 2^{1 / a}(1-t)\right)$

Evidently, the median voter will not decide on a positive tax rate if at this tax rate she chooses to consume a privately provided variety (since in such a case would consent to a drop to her disposable income without the benefit of consuming the publicly provided variety $)^{2}$. Thus, if the tax rate preferred by the median voter is positive, we find from equation (14) that the maximum value of $V_{m}^{G}$ is attained if the tax rate is ${ }^{3}$,

\footnotetext{
${ }^{2}$ The implication of this is that the household which will be indifferent between a privately offered and the publicly offered variety will have higher income than the median voter $(\theta>m)$.

${ }^{3}$ The second order condition is satisfied. Note also that in order for this tax rate to be the median voter's optimal choice it must also be the case that the utility it confers to the median voter is higher than that which the median voter would attain at a zero tax rate, i.e., $V_{m, t^{*}}^{G}=\frac{b a}{(a-1)\left(1-(b / \theta)^{a}\right)}-1+\ln \left(b 2^{1 / a}\left(1-t^{*}\right)\right)>b 2^{1 / a}-1=V_{m, t=0}^{P}$. This is the case for empirically relevant values of $a$.
} 
$t^{*}=1-\left\{(a-1)\left(1-(b / \theta)^{a}\right) / b a\right\}$.

We note from equation (15) that the median voter's preferred tax rate $\left(t^{*}\right)$ decreases if ceteris paribus - the proportion of households consuming the publicly provided variety $\left(=1-(b / \theta)^{a}\right)$ increases. But, of course, the proportion of households that consume the publicly provided variety itself depends on the ruling tax rate (which is the one preferred by the median voter); a higher $t^{*}$ leaves households with lower disposable income thus inducing some of them to switch from consuming a privately supplied variety to the publicly supplied. From equation (10) and using equations (12) and (15) we get another relationship between $t^{*}$ and the dividing level of income $(\theta)$,

$\theta\left(1-t^{*}\right)-\left(1 /\left(1-t^{*}\right)\right)=\ln \left(\theta\left(1-t^{*}\right)\right)$

Equations (15) and (16) jointly allow the median voter to determine $t^{*}$ (and $\theta$ ). Since we are interested in the effects of mean-preserving changes in income distribution on $t^{*}$, we consider the effects of changes in the shape parameter of the Pareto distribution ( $a$ ) that keep average income $(=\mu)$ constant. An increase in $a$ (which also results in a decline in the ratio of mean to median income, and is therefore inequality reducing), must thus be paired with an increase in parameter $b$ in order for $\mu$ to remain constant. As the reader can easily verify the comparative statics effects of changes in $a$ on $t^{*}$ are ambiguous. After extensive experimentation with empirically relevant parameter values (which also satisfy the condition expressed in footnote 1), we find that changes in inequality exert (practically) no effect on $t^{*}$. Figure 1 displays the median voter's preferred tax rates (size of government) as a function of inequality and for three different values of average income ( $\mu=2.0,2.5,3.0$ - black, red and green schedules, respectively). 


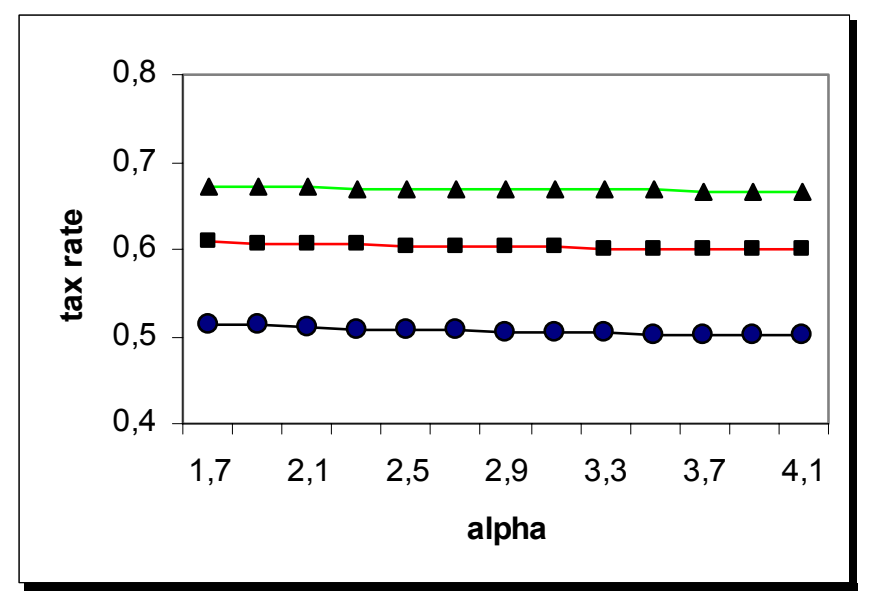

Figure 1: Government size and inequality

The explanation for this result relies on the fact that a rise in the tax rate in response to an increase in inequality implies the combination of two effects. The first one is the traditional effect identified in the literature which leads to an increase in the tax rate preferred by the median voter as the gap between mean and median (pre-tax) income increases - since the median voter expects that a rise in the tax rate will bring to her a greater increase in public goods provision than before. But in addition to this, a higher tax rate will induce some highincome households to switch their demand from a privately supplied variety to the publicly supplied. Accordingly, the government may not be able to use the increased tax revenue to produce a variety of higher quality, as it will have to provide the good to a higher number of households. It is thus by no means certain that a higher tax rate will procure the median voter (and everyone else) a higher quality of the public good. Our numerical results show that the two effects mentioned tend to cancel each other, producing a non-monotonic and rather insignificant effect of inequality on the tax rate (size of government).

\section{Conclusion}

In this paper we consider what happens if the government can redistribute through both sides of its budget (revenue and expenditure). We model this by introducing the possibility that high-income individuals may decide not to "consume" what the government is offering as a 
public good to all citizens. We find that changes in inequality may have no discernible effect on the size of government.

\section{References}

Alesina, A. and D. Rodrik (1994), "Distributive politics and economic growth", Quarterly Journal of Econmics, 109, pp. 465-490.

Alesina, A., E. Glaeser, and B. Sacerdote (2001),"Why doesn't the US have a European-style welfare system”, Brookings Papers on Economic Activity, pp. 187-278.

Benabou, R. (1996) "Inequality and growth", in R. Bernanke and J. Rotemberg, (eds.), NBER Macroeconomics Annual, 11-74, NBER, Cambridge, Mass.

Benabou, R. (2000), "Unequal societies: Income distribution and the social contract", American Economic Review, 90, pp. 96-129.

Creedy, J. (1977), "Pareto and the distribution of income," Review of Income and Wealth, 23, pp. 405-411.

Flam, H. and E. Helpman, (1987), "Vertical product differentiation and North-South trade", American Economic Review, 77, pp. 810-822.

Lee, W. and J. Roemer (1999),“Inequality and redistribution revisited”, Economics Letters, 65, pp. 339-346.

Meltzer, A. and S. Richard (1981), "A rational theory of the size of government", Journal of Political Economy, 89, pp. 914-27.

Meltzer, A. and S. Richard, (1983), “Tests of a rational theory of the size of government”, Public Choice, 41, 403-18.

Milanovic, B. (2000), "The median-voter hypothesis, income inequality, and income redistribution: an empirical test with the required data", European Journal of Political Economy, 16, pp. 367-410.

Persson, T. and G. Tabellini (1994), “Is inequality harmful for growth?”, American Economic Review, 84, pp. 600-621.

Rodriguez, F.C. (1999), "Does distributional skewness lead to redistribution? Evidence from the United States," Economics and Politics, 11(2): 171-99. 


\section{CESifo Working Paper Series}

(for full list see www.cesifo.de)

1054 Martin R. West and Ludger Wößmann, Which School Systems Sort Weaker Students into Smaller Classes? International Evidence, October 2003

1055 Annette Alstadsaeter, Income Tax, Consumption Value of Education, and the Choice of Educational Type, October 2003

1056 Ansgar Belke and Ralph Setzer, Exchange Rate Volatility and Employment Growth: Empirical Evidence from the CEE Economies, October 2003

1057 Carsten Hefeker, Structural Reforms and the Enlargement of Monetary Union, October 2003

1058 Henning Bohn and Charles Stuart, Voting and Nonlinear Taxes in a Stylized Representative Democracy, October 2003

1059 Philippe Choné, David le Blanc and Isabelle Robert-Bobée, Female Labor Supply and Child Care in France, October 2003

1060 V. Anton Muscatelli, Patrizio Tirelli and Carmine Trecroci, Fiscal and Monetary Policy Interactions: Empirical Evidence and Optimal Policy Using a Structural New Keynesian Model, October 2003

1061 Helmuth Cremer and Pierre Pestieau, Wealth Transfer Taxation: A Survey, October 2003

1062 Henning Bohn, Will Social Security and Medicare Remain Viable as the U.S. Population is Aging? An Update, October 2003

1063 James M. Malcomson, Health Service Gatekeepers, October 2003

1064 Jakob von Weizsäcker, The Hayek Pension: An efficient minimum pension to complement the welfare state, October 2003

1065 Joerg Baten, Creating Firms for a New Century: Determinants of Firm Creation around 1900, October 2003

1066 Christian Keuschnigg, Public Policy and Venture Capital Backed Innovation, October 2003

1067 Thomas von Ungern-Sternberg, State Intervention on the Market for Natural Damage Insurance in Europe, October 2003

1068 Mark V. Pauly, Time, Risk, Precommitment, and Adverse Selection in Competitive Insurance Markets, October 2003 
1069 Wolfgang Ochel, Decentralising Wage Bargaining in Germany - A Way to Increase Employment?, November 2003

1070 Jay Pil Choi, Patent Pools and Cross-Licensing in the Shadow of Patent Litigation, November 2003

1071 Martin Peitz and Patrick Waelbroeck, Piracy of Digital Products: A Critical Review of the Economics Literature, November 2003

1072 George Economides, Jim Malley, Apostolis Philippopoulos, and Ulrich Woitek, Electoral Uncertainty, Fiscal Policies \& Growth: Theory and Evidence from Germany, the UK and the US, November 2003

1073 Robert S. Chirinko and Julie Ann Elston, Finance, Control, and Profitability: The Influence of German Banks, November 2003

1074 Wolfgang Eggert and Martin Kolmar, The Taxation of Financial Capital under Asymmetric Information and the Tax-Competition Paradox, November 2003

1075 Amihai Glazer, Vesa Kanniainen, and Panu Poutvaara, Income Taxes, Property Values, and Migration, November 2003

1076 Jonas Agell, Why are Small Firms Different? Managers’ Views, November 2003

1077 Rafael Lalive, Social Interactions in Unemployment, November 2003

1078 Jean Pisani-Ferry, The Surprising French Employment Performance: What Lessons?, November 2003

1079 Josef Falkinger, Attention, Economies, November 2003

1080 Andreas Haufler and Michael Pflüger, Market Structure and the Taxation of International Trade, November 2003

1081 Jonas Agell and Helge Bennmarker, Endogenous Wage Rigidity, November 2003

1082 Fwu-Ranq Chang, On the Elasticities of Harvesting Rules, November 2003

1083 Lars P. Feld and Gebhard Kirchgässner, The Role of Direct Democracy in the European Union, November 2003

1084 Helge Berger, Jakob de Haan and Robert Inklaar, Restructuring the ECB, November 2003

1085 Lorenzo Forni and Raffaela Giordano, Employment in the Public Sector, November 2003

1086 Ann-Sofie Kolm and Birthe Larsen, Wages, Unemployment, and the Underground Economy, November 2003 
1087 Lars P. Feld, Gebhard Kirchgässner, and Christoph A. Schaltegger, Decentralized Taxation and the Size of Government: Evidence from Swiss State and Local Governments, November 2003

1088 Arno Riedl and Frans van Winden, Input Versus Output Taxation in an Experimental International Economy, November 2003

1089 Nikolas Müller-Plantenberg, Japan’s Imbalance of Payments, November 2003

1090 Jan K. Brueckner, Transport Subsidies, System Choice, and Urban Sprawl, November 2003

1091 Herwig Immervoll and Cathal O'Donoghue, Employment Transitions in 13 European Countries. Levels, Distributions and Determining Factors of Net Replacement Rates, November 2003

1092 Nabil I. Al-Najjar, Luca Anderlini \& Leonardo Felli, Undescribable Events, November 2003

1093 Jakob de Haan, Helge Berger and David-Jan Jansen, The End of the Stability and Growth Pact?, December 2003

1094 Christian Keuschnigg and Soren Bo Nielsen, Taxes and Venture Capital Support, December 2003

1095 Josse Delfgaauw and Robert Dur, From Public Monopsony to Competitive Market. More Efficiency but Higher Prices, December 2003

1096 Clemens Fuest and Thomas Hemmelgarn, Corporate Tax Policy, Foreign Firm Ownership and Thin Capitalization, December 2003

1097 Laszlo Goerke, Tax Progressivity and Tax Evasion, December 2003

1098 Luis H. B. Braido, Insurance and Incentives in Sharecropping, December 2003

1099 Josse Delfgaauw and Robert Dur, Signaling and Screening of Workers' Motivation, December 2003

1100 Ilko Naaborg,, Bert Scholtens, Jakob de Haan, Hanneke Bol and Ralph de Haas, How Important are Foreign Banks in the Financial Development of European Transition Countries?, December 2003

1101 Lawrence M. Kahn, Sports League Expansion and Economic Efficiency: Monopoly Can Enhance Consumer Welfare, December 2003

1102 Laszlo Goerke and Wolfgang Eggert, Fiscal Policy, Economic Integration and Unemployment, December 2003

1103 Nzinga Broussard, Ralph Chami and Gregory D. Hess, (Why) Do Self-Employed Parents Have More Children?, December 2003 
1104 Christian Schultz, Information, Polarization and Delegation in Democracy, December 2003

1105 Daniel Haile, Abdolkarim Sadrieh and Harrie A. A. Verbon, Self-Serving Dictators and Economic Growth, December 2003

1106 Panu Poutvaara and Tuomas Takalo, Candidate Quality, December 2003

1107 Peter Friedrich, Joanna Gwiazda and Chang Woon Nam, Development of Local Public Finance in Europe, December 2003

1108 Silke Uebelmesser, Harmonisation of Old-Age Security Within the European Union, December 2003

1109 Stephen Nickell, Employment and Taxes, December 2003

1110 Stephan Sauer and Jan-Egbert Sturm, Using Taylor Rules to Understand ECB Monetary Policy, December 2003

1111 Sascha O. Becker and Mathias Hoffmann, Intra-and International Risk-Sharing in the Short Run and the Long Run, December 2003

1112 George W. Evans and Seppo Honkapohja, The E-Correspondence Principle, January 2004

1113 Volker Nitsch, Have a Break, Have a ... National Currency: When Do Monetary Unions Fall Apart?, January 2004

1114 Panu Poutvaara, Educating Europe, January 2004

1115 Torsten Persson, Gerard Roland, and Guido Tabellini, How Do Electoral Rules Shape Party Structures, Government Coalitions, and Economic Policies? January 2004

1116 Florian Baumann, Volker Meier, and Martin Werding, Transferable Ageing Provisions in Individual Health Insurance Contracts, January 2004

1117 Gianmarco I.P. Ottaviano and Giovanni Peri, The Economic Value of Cultural Diversity: Evidence from US Cities, January 2004

1118 Thorvaldur Gylfason, Monetary and Fiscal Management, Finance, and Growth, January 2004

1119 Hans Degryse and Steven Ongena, The Impact of Competition on Bank Orientation and Specialization, January 2004

1120 Piotr Wdowinski, Determinants of Country Beta Risk in Poland, January 2004

1121 Margarita Katsimi and Thomas Moutos, Inequality and Redistribution via the Public Provision of Private Goods, January 2004 